\title{
SUJ2 研削材の長寿命域疲労特性に及ぼす表面硬化層除去の影響十
}

$\begin{array}{llll}\text { 後 藤 真 宏* } & \text { 山本 隆 栄* } \\ \text { 酒 井 達 雄 } & \text { 西 } \text { 胧籠石 紀 雄 }^{* * *} \text { 信** }\end{array}$

\section{Effect of Removing Surface Hardened Layer on the Fatigue Strength of Bearing Steel SUJ2 Ground Specimen in the Long Life Field}

\author{
by \\ Masahiro Goтo*, Takaei Yамамото * , Hironobu Nistrani ${ }^{* *}$ \\ Tatsuo SAKAI $^{* * *}$ and Norio KAWAGOISHI ${ }^{* * * *}$
}

\begin{abstract}
In order to study the fatigue damage of a high carbon chromium bearing steel SUJ2, rotating bending fatigue tests of smooth specimens $\left(K_{t}=1.06\right.$, stress concentration factor) were carried out. The specimens were finished by the grinding after the heat-treatment. The fatigue strength of EP-0 (ground) specimen exhibited large scatter and it tended to drop again in the long-life field in excess of $10^{7}$ cycles. In such a case, fish-eye was left on the fracture surface. In order to study the effect of surface hardened layer due to the grinding, two types of EP (electropolished) specimens, EP-15 specimen whose surface hardened layer and grinding flows were almost removed and EP-3 specimen which has the decreased surface roughness and surface hardened layer, were fatigued. The fatigue strength of EP-15 specimen was dramatically decreased when compared to the EP-0 specimen, and no drop in fatigue strength in the long-life field were observed. This indicates that the drop in fatigue strength in the long-life field results from the surface strengthened layer due to the grinding. On the other hand, S-N data of EP-3 specimen exhibit large scatter, but the range of scatter is smaller than that of EP- 0 specimen. This narrowed scatter may be related to the decreased surface roughness of EP-3 specimen. Considering the experimental results of EP - 15 and -3 specimens, the physical basis of peculiar S-N characteristics of EP-0 specimen was investigated.
\end{abstract}

Key words : Ultra high-cycle fatigue, High strength steel, Fish-eye, Rotating bending, S-N characteristics, Grinding, Residual stresses, Work-hardening, SEM, Surface roughness

\section{1 緒言}

高強度鋼や表面硬化処理材などの S-N 曲線が一旦水平 になった後, $10^{7}$ 回付近から疲労強度が再び低下寸る事 例が最近多数報告されている. ${ }^{1)}$ ９) また，このような場 合，破面にはフィッシュアイが観察されることが多い． ところで, 機械・構造物の中には従来の $10^{7}$ 回疲労限度 を基準に設計され，設計時の耐用年数を超えてな打稼動 しているものもある.従って，これら部材の余寿命評 価・耐用年数の延長における信頼性評価の観点から, 長 寿命域の疲労特性を検討する意味は大きい。このため, 長寿命域疲労特性に関する研究は最近增加して打り, 疲 労データの集積が進むとともに，いくつかの知見が明ら かにされている。

一方，高強度鋼の試験片を製作する場合，予め試験片 形状近くまで加工した後熱処理を施し, 研削により最終 形状へ仕上げる工程が一般的である。すすなわち, 試験片 表面には研削による加工硬化層打よび加工傷が残される。 疲労き裂は多くの場合試験片表面から発生するので, 表 面傷や加工硬化層が疲労強度特性に及ぼす影響を明らか にする必要がある。また，表面硬化処理材に見られるよ
うに, 表面が硬化されることにより破壊の起点が試験片 内部に移行することも考えられる。高強度鋼の疲労強度 に及ぼす研削加工の影響に関して，これ迄にも加工硬 化・残留応力・表面粗さおよび組織変化など個々の観点 から検討されている ${ }^{10)}$ 13) が，その影響を長寿命域まで 含めて検討した研究はほとんどないようである.

本研究では，以上のことを考慮して高炭素クロム軸受 鋼 SUJ2 の回転曲げ疲労試験を行った。その際，研削仕 上げのままの試験片, 表面硬化層の大部分を電解研磨に より除去した試験片，および表面硬化層は有するが表面 粗さの影響を電解研磨により小さくした試験片について 実験を行い，研削加工が長寿命域を含む疲労強度に及ほ す影響を明らかにした。

\section{2 実 験 方 法}

素材は市販の高炭素クロム鋼 SUJ2（直径：14.3mm） である. Table Iに素材の化学成分を, Fig. 1 に以下に 示す熱处理を行った後の組織写真をそれぞれ示す。

Fig. 2 に, 試験片形状を示す. 研削仕上げのままの試 験片は, 研削代 $0.1 \mathrm{~mm}$ を見込んで切削加工後, 真空炉 中で焼入れ $\left(835^{\circ} \mathrm{C}, 40 \mathrm{~min} \rightarrow\right.$ 油冷 $\left.80^{\circ} \mathrm{C}\right) \cdot$ 焼もどし

$\dagger \quad$ 原稿受理 平成 11 年 8 月 23 日 Received Aug 23,1999

* 正 会 員 大分大学工学部生産システム工学科 テ870-1192 大分市旦野原, Dept. of Mech. Eng., Oita Univ., Dan-noharu, Oita, 870-1192

** . 正 会員 九州産業大学工学部機械工学科 †813-8503 福岡市東区松香台, Dept. of Mech. Eng., Kyusyu-Sangyo Univ., Higashi-ku, Fukuoka, 813-8503

*** 正 会 員 立命館大学理工学部機械工学科 \%525-8577 草津市野路東, Dept. of Mech. Eng., Ritsumeikan Univ., Nojihigashi, Kusatsu, 525-8577

**** 正 会 員 鹿児島大学工学部機械工学科 †890-0065 鹿児島市郡元, Dept. of Mech. Eng., Kagoshima Univ., Koorimoto, Kagoshima, 890-0065 
$\left(180^{\circ} \mathrm{C}, 2 \mathrm{hr} \rightarrow\right.$ 空冷）を行い（蓺処理後の引張り強さ $\sigma_{u}$ = 2316MPa）, 円筒研削にて最終仕上げを行ったもので 西る(仕上げ記号わに相当)。試験片の切欠き（切欠 き半径 $7 \mathrm{~mm}$ ）による応力集中係数は $K_{t}=1.06$ であり， 切欠き部横断面のビッカース硬さ $H_{v}$ の平均值は $H_{v}=$ 777 である(荷重： $P=2.94 \mathrm{~N}$ )。また, 表面加工硬化層 の大部分を除去した試験片は, 研削仕上げ後電解研磨に より表面を $15 \mu \mathrm{m}$ 程度除去したものである。一方, 加工 硬化層は残し表面粗さを小さくした試験片は，電解研磿 にて表面を $3 \mu \mathrm{m}$ 程度取り除いたものである，以後，研削 仕上げ材を EP-0 材（電解研磨量 $0 \mu \mathrm{m}$ ），また電解研磨材 をそれぞれ EP-15 材扔よびEP-3 材と呼ぶ。

用いた試験機は 4 連式片持ち回転曲げ瘦労試験機 $(3,150 \mathrm{rpm})$ である。応力 $\sigma_{a}$ は, 切欠き底の最大応力振 幅で定義した。また, 研削仕上げ材の疲労限度は $10^{7}$ 回 を打切り繰返し数とし，10 本の試験片を用いてステアケ

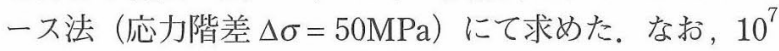
回で破断しなかった試験片は, 実験を継続し破断に至る まで繰返した。

\section{3 実験結果および考察}

\section{3・1 研削仕上げ材（EP-0 材）の S-N 特性}

Fig. 3 に，EP-0 材の S-N 曲線を示す。ばらつきはかな り大きいが $N<10^{5}$ では S-N 曲線を傾いた直線で, その 後 $N=10^{7}$ 回まで水平線で近似できる.10 本の試験片に よるステアケース法から求めた疲労限度は $\sigma_{w 0}=1200 \mathrm{MPa}$ $\left(s=31.08 \mathrm{MPa}, s\right.$ : 標準偏差) である。一方, $N=10^{7}$ 回 を超气る繰返し数領域では疲労強度が再度低下する（例 えば， $\sigma_{a}=1000 \mathrm{MPa}$ では, $N=6.97 \times 10^{8}$ 回にて破断す る例が認められた)。以上のように，本材の S-N曲線に は，他の高強度鋼や表面処理材で報告されているいわゆ る2段折机曲がり現象が認められる。

Table I. Chemical composition (wt \%).

\begin{tabular}{|ccccccccr|}
\hline $\mathrm{C}$ & $\mathrm{Si}$ & $\mathrm{Mn}$ & $\mathrm{P}$ & $\mathrm{S}$ & $\mathrm{Cr}$ & $\mathrm{Cu}$ & $\mathrm{Ni}$ & $\mathrm{Mo}$ \\
\hline 1.01 & 0.23 & 0.36 & 0.012 & 0.007 & 1.45 & 0.06 & 0.04 & 0.02 \\
\hline
\end{tabular}

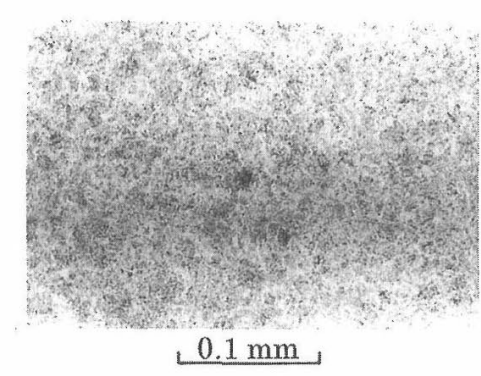

Fig. 1. Microstructure of the material.

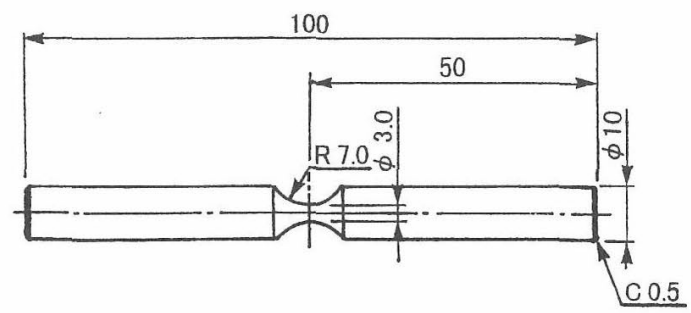

Fig. 2. Shape and dimensions of the specimen.
この特異な疲労現象を実験的に検討するため，著者の 1 人が代表を務める材料強度確率モデル研究会 (RGSAMS) では，独自に開発した 4 連式片持ち回転曲げ度労試験機 を多数設置し，同一材料・共通試験片による共同実験を 計画的に実施している。研削仕上げ材による本実験はこ の共同実験の一環として行われたものである.Fig. 4 は, 現時点で得られている RGSAMSの共同実験による S-N データに，本実験結果（図3）を重ねてプロットしたも のである、本実験結果（○，（）は，RGSAMS データ上 に分布しており，傾向的にも同じ結果といえる。そこで， 後に電解研磨材と S-N 特性の比較を行う際には, 研削材 として RGSAMS の結果を使うことにする。なお，Fig. 3， 4 において○，印は，フィッシュアイが破面に認めら れな試験片を意味する。

Fig. 5 に，EP-0 材の破面の SEM 観察結果を示す. (a) は破断繰返し数が小さい場合 $\left(N_{f}<10^{6}\right)$ の典型的な破 面であり，破壊の起点は表面にあり起点付近に介在物な どの欠陥は認められない。破断繰返し数の大きい (b), (c) では，破面にフィッシュアイが観祭され，フィッシ ユアイの中心部には非金属介在物が存在する。 $10^{7}$ 回を 越える長寿命で破断した (c) では，介在物の周辺に凹凸 の激しい粗い破面が観察され，き裂が通常の疲労機構と 異なる機構で極めてゆっくり伝ぱしたと思われる。村上 $ら^{14)}$ は, この領域をダークエーリアと呼び詳細な検討を 加え, 介在物周辺に集積した水素の影響と繰返し応力と の連成による遅れ破壊と類似のき裂伝ぱ機構を提案して

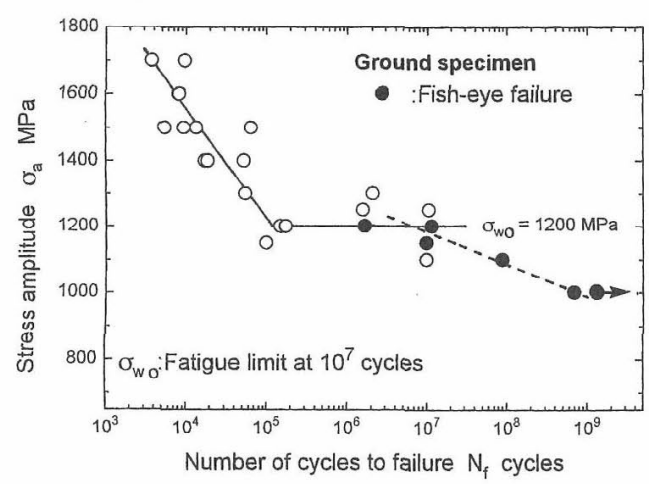

Fig. 3. S-N data of the EP-0 (ground) specimen.

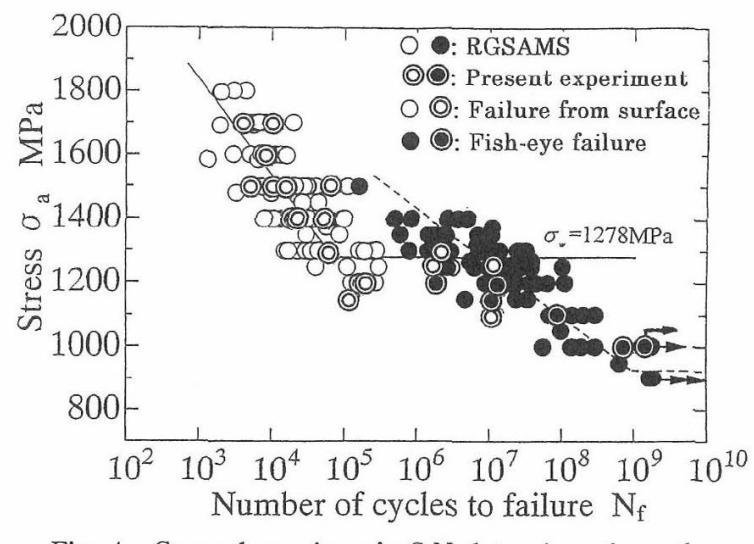

Fig. 4. Ground specimen's S-N data given from the RGSAMS (@) and symbols are the results of the present experiments). 
いる。また，(b) の場命の介在物はフィッシュアイの中 心より表面側にずれ，かつ表面のごく近傍（表面下約 $20 \mu \mathrm{m} ） に$ 位置する。このことは，研削による影響域が表 面付近に存在することを示惨する。一方，(c) は欠陥が 表面よりかなり深く表面層の影響をほとんど受けず，か つ曲げによる応力場が内部方向に向かって減少すること により, 介在物はフィッシュアイの中心より試験片中心 側にややずれて位置する。本試験片半径は $1.5 \mathrm{~mm}$ であ ることから, 起点深さに効応する応力を用いれば表面の 応力により整理した長寿命域の S-N 特性 (Fig. 3，4) は異 なることが予想される（例えば，(c) の場合は，起点は 表面から $0.21 \mathrm{~mm}$ の深さにあり単純に考学ても公称応力 は $14 \%$ 減少する)。

\section{$3 \cdot 2$ 疲労強度に及ぼす表面層除去の影響}

研削材では, 疲労寿命のばらつきが著しく大きいこと， $10^{7}$ 回瘦労限度付近では破壞起点が表面にある試験片と 内部にある試験片が混在すること, 内部起点形の破壊で は破断までに要する繰返し数が著しく大きい $\left(N_{f}>10^{7}\right.$ 回）ことが示された。疲労強度に及ぼす研削仕上げの主 な影響として，(1) 加工硬化による材質強化，(2) 圧縮 残留応力（これは平均応力に相当する効果をもつ），(3) 研削傷など表面の幾何学的形状による切欠き効果（これ はばらつきを有する) などが考えられる。(1)，(2) は疲労 強度を増加させる方向に，(3) は減少させる方向に作用し かつばらつきにも関係する。ここでは，(1)〜 (3) の効果

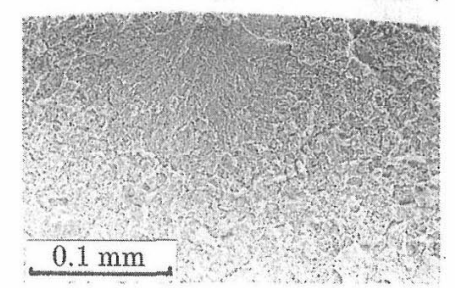

(a) $\sigma_{a}=1200 \mathrm{MPa}, N_{f}=1.523 \times 10^{5}$
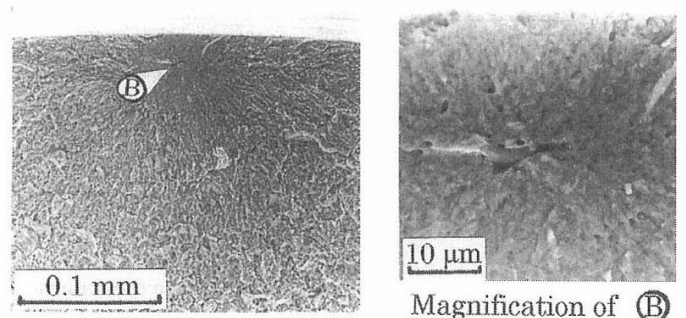

(b) $\sigma_{a}=1200 \mathrm{MPa}, N_{f}=1.692 \times 10^{6}$
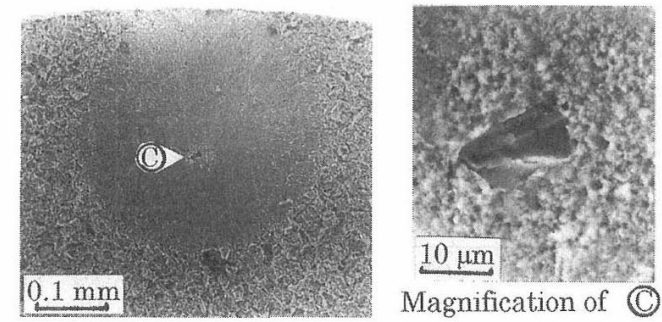

(c) $\sigma_{a}=1000 \mathrm{MPa}, N_{f}=6.965 \times 10^{8}$

Fig. 5. SEM observations of fracture surface of the EP-0 specimen.
に着目して研削が疲労強度に及ぼす影響を検討する。そ のため, 電解研磨量 $0 \mu \mathrm{m}$ の研削材（EP-0 材）に加え，表 面硬化層をほほ除去した試験片（EP-15材），および表面 硬化層は有するが表面粗さの影響を少なくした試験（EP3 材）の実験を新たに行い，EP-0 材との比較を行った。

Fig. 6 (a) に, EP-0 材, EP-3 材, EP-15 材の表面の顕 微鏡写真, および (b) に試験片軸方向に測定した表面粗 さを示す。図に示したそれ爷机の場合の表面粗さ $R_{\text {max }}$ は， $\mathrm{EP}-0$ 材が $R_{\text {max }}=6.36 \mu \mathrm{m}, \mathrm{EP}-3$ 材が $R_{\text {max }}=1.96 \mu \mathrm{m}, \mathrm{EP}-$ 15 材が $R_{\text {max }}=0.64 \mu \mathrm{m}$ である。これより電解研磨により 凹凸が平均化され，すなわち表面の幾何学的形状のばら つきは減少する。

Table IIに，表面において測定した残留応力の值を示 す. EP-0 材では, 試験片軸方向に-500MPaを越える圧 縮の残留応力が発生している。 EP-3 材でも, $-350 \mathrm{MPa}$ 程度の残留応力が認められるが, EP-15 材では残留応力 はほとんど消滅している。

Fig. 7 (a) に, 試験片横断面の硬さ分布と表面の硬さ を測定した結果（荷重 $P=2.94 \mathrm{~N} ）$ を示す。試験片内部 の硬さは表面近傍 $0.1 \mathrm{~mm}$ から中心部までほぼ一様であ り，乤の平均值は $H_{v}=777$ である。 ○印で表面の硬さを 示す. EP-0 材では表面の $H_{v}=995$ であり，研削により 表面層は加工硬化している，EP-3 材では $H_{v}=910 ，$ EP15 材では $H_{v}=821$ である. Fig. 7 (b) に，表面硬さの対 数と電解研磨量の関係を示す。ばらつきは大きいが両者 の関係は大雑把には直線で近似できる。これと内部の硬 さが $H_{v}=777$ であることから研削による影響域の深さは 表面から $20 \sim 25 \mu \mathrm{m}$ 程度と推測される.

Fig. 8 に, EP-3 材と EP-15 材の S-N 曲線を示す. EP15 材の S-N 曲線は電解研磨した各種炭素鋼や低合金鋼 などに見られる典型的な形状をしており，明確な疼労限 度が存在する。瘦労限度は $\sigma_{w 15}=750 \mathrm{MPa}$ であり，これ は EP-0 材 $\left(\sigma_{w 0}=1200 \mathrm{MPa}=1.6 \sigma_{w 15}\right)$ よりかなり小さく, 僅か $15 \mu \mathrm{m}$ の表面層除去が疲労強度を大きく低下させる。 また, 疲労寿命のばらつきは小さく S-N 曲線は1 本の曲 線で近似できる。EP-15 材の S-N 曲線のばらつきが小さ いことは，熱処理による素材自体のばらつきがそれほど 大きくないことを意味する。このことは，EP-0 材の S-N データのばらつき（Fig. 3，4）が研削仕上げに起因する ことを示唆している。Fig. 9 (a) E EP-15材の破面の SEM 写真の一例を示す. 全ての試験片で破壊起点は表 面にあり，き裂は表面すべりから発生したと思われる (電解研磨により介在物が抜け落ちた跡，扎よび表面の介 在物が起点となって破壊した例も 1 例づつ認められた)。 一方, EP-3 材では疲労強度のばらつきはEP-15 材より大 きい. EP-3 材の破面の SEM 写真を Fig. 9 (b), (c) (d) に示す。短寿命域 $\left(N<10^{6}\right.$ 回) では起点は表面 (b) にあ

Table II . Residual stresses measured at the specimen surface.

\begin{tabular}{|l|c|c|}
\hline \multirow{2}{*}{ Specimen } & \multicolumn{2}{|c|}{ Residual stresses MPa } \\
\cline { 2 - 3 } & $\begin{array}{c}\text { Axial } \\
\text { direction }\end{array}$ & $\begin{array}{c}\text { Circumferential } \\
\text { direction }\end{array}$ \\
\hline EP-0 (ground) & -517 & -429 \\
\hline EP-3 & -364 & -269 \\
\hline EP-15 & 79 & -74 \\
\hline
\end{tabular}




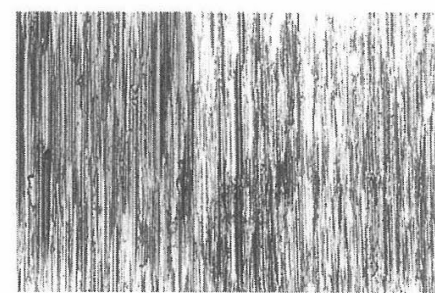

Ground specimen

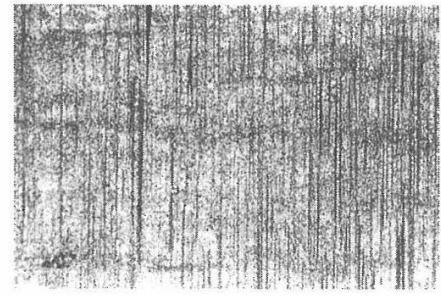

Electropolished (3 $\mu \mathrm{m})$

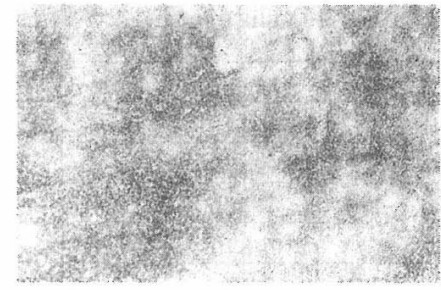

Electropolished $(15 \mu \mathrm{m})$

$\Leftrightarrow$ : Axial direction, $0.1 \mathrm{~mm}$

(a) Micrograph of the surface

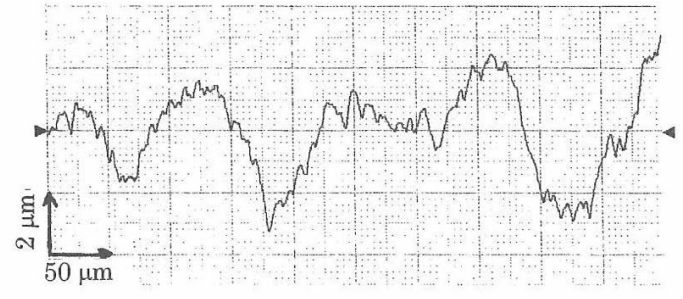

Gr specimen, $\quad R_{\max }=6.36 \mu \mathrm{m}$

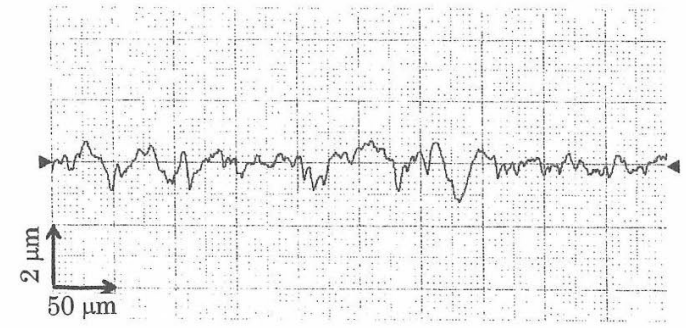

EP-3 specimen, $\quad R_{\max }=1.96 \mu \mathrm{m}$

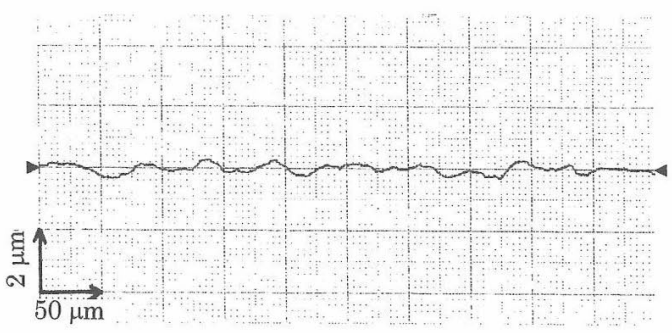

EP-15 specimen, $\quad R_{\max }=0.64 \mu \mathrm{m}$

(b) Surface roughness

Fig. 6. Surface morphology and roughness for each specimen.

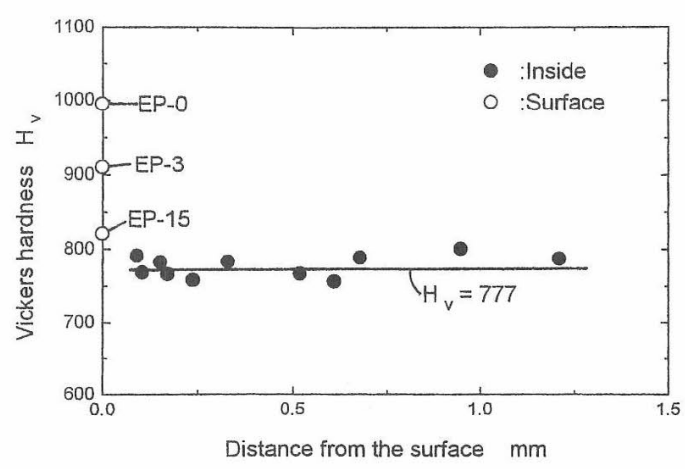

(a) Hardness over the cross section and at the surface

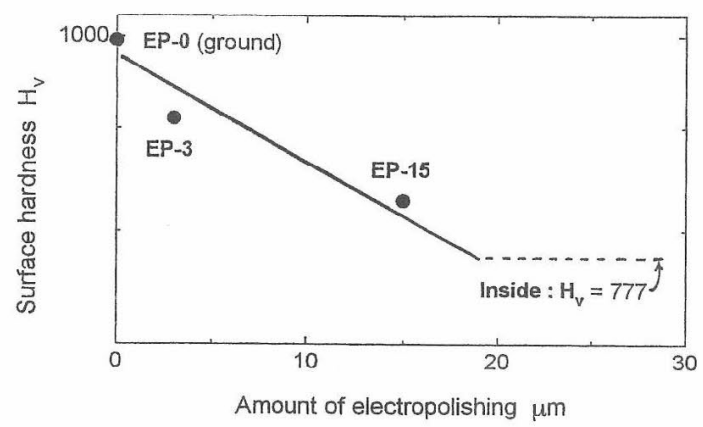

(b) Relation between surface hardness and amount of electroplishing

Fig. 7. Vickers hardness for each specimen.

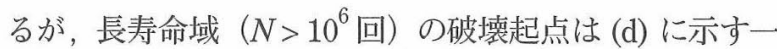
例を除いて全て内部 (c) にあった。(d) は $\sigma_{a}=1100 \mathrm{MPa}$ の繰返しにより $N_{f}=2.102 \times 10^{7}$ 回にて表面から破壞した 試験片である。この場合のき裂発生起点は研削傷底（深

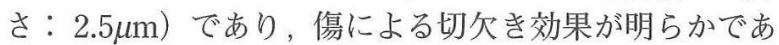
る。破面にフィッシュアイが認められた試験片を Fig. 8 にム印で表す。また，EP-3 材の疲労寿命のばらつきの上 下限を 2 本の実線で示す。EP-3 材の疲労寿命の下限は EP-15 材の S-N 曲線に近い. $15 \mu \mathrm{m}$ の表面層除去は $3 \mu \mathrm{m}$ 除去に比べ, 疲労強度を増加させる硬さおよび圧縮残留
応力を減少させる, 反面疲労強度低下の原因となる表面 傷や割れをほぼ完全に取除く。西谷らは, ペーパーによ る表面仕上げ状態の異なる $\mathrm{S} 45 \mathrm{C}$ 調質材 $\left(\sigma_{u}=981 \mathrm{MPa}\right.$, $H_{v}=308$ ) の回転曲げ瘦労試験を行い，軸方向研磨材を基 準としたとき周方向研磨では $R_{\max }=2 \sim 3 \mu \mathrm{m}$ で表面係 数が $m=0.96$ 程度になることを報告 ${ }^{15)}$ している。本材料 はこれよりはるかに硬いことから, 切欠き感度は高く $R_{\text {max }}$ $=2 \mu \mathrm{m}$ 以下の傷でも瘦労強度に影響すると思われる。

Table IIIに, EP-3 材について疲労寿命のばらつきの上 下限付近に位置する試験片について, 破断後, 表面の硬 
さを測定した結果と破断繰返し数を示す。応力レベルに 無関係に，寿命上限で破断した試験片の硬さは $H_{v}=941$ 〜 954 であるが，寿命下限で破断した場合は $H_{v}=862$ 〜 887 と, 表面硬さと寿命上下限とは対応している。こ の硬さの違いは，表面除去量抢よび加工硬化の程度のば らつきに起因したものと考えられる。なお，EP-0 材の疲 労寿命のばらつき (Fig. 4) に特徵的な傾向が確認されな いことから，試験片ごとの研削後の表面硬さに傾向的な 違いはなかったものと推測される。一方，EP-15材の表 面除去量は $3 \mu \mathrm{m}$ よりかなり大きいため, 電解研磨量のば らつきに起因した S-N 曲線のばらつきは無視できる。表 中の*印は，内部起点形で破壇した試験片を示す。内部 破壊した試験片の表面硬さは $H_{v}>930$ であり，寿命下 限で破断した試験片より硬さは大きい。本材料における 内部破壊の場合，表面硬さの上昇は内部き裂発生機構と 直接関係しないが，表面硬さの上昇がなければき裂が試 験片内部から発生する必然性はなく常に表面から発生す る。従って，本材料において内部破壤が生じるためには

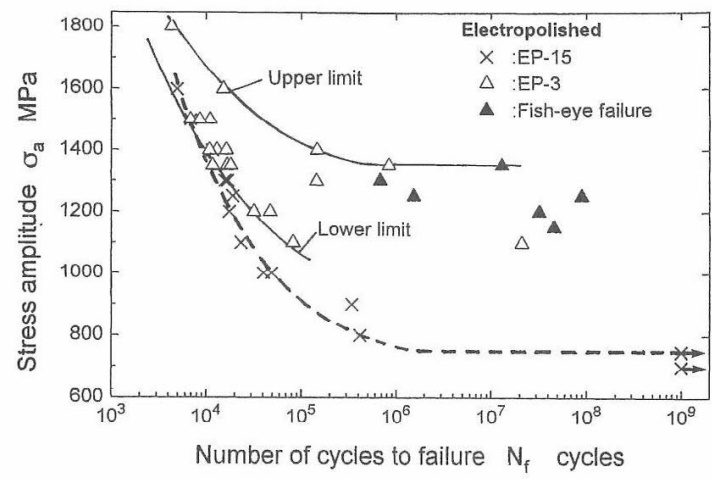

Fig. 8. S-N plots for EP-3 and EP-15 specimens.

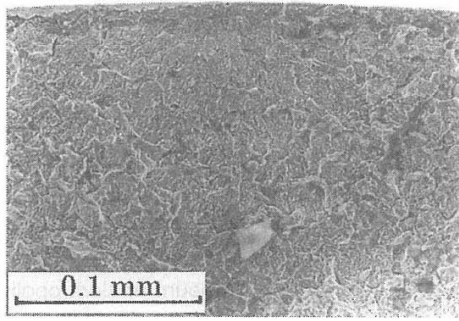

(a) EP-15

$\sigma_{a}=1000 \mathrm{MPa}, N_{f}=4.034 \times 10^{4}$
表面硬さの上昇は必要である。

Fig. 10 は，EP-0 材（RGSAMSのデータ）と EP-3 材 それぞれの S-N データのばらつきの上下限と EP-15 材の S-N 曲線を同時に示したものである。EP-0 材に比べ EP3 材のばらつきの幅が小さいことが分かる。EP-3 材では, 電解研磨量の不揃いと加工硬化のばらつきによる表面硬 さの違いが存在するにも拘わらず (Table III ), S-N 曲線 のばらつきの幅が EP-0 材より小さくなった理由として， 表面の幾何学的形状のばらつきが小さくなったことが挙 げられる。Fig. 11 に EP-3材の寿命下限近くで破断した 試験片の破断前後に扔けるき裂発生場所付近の表面状態 を示す。き裂発生点付近に浅い傷は存在するが，EP-0 材 に認められる深く鋭い傷は観察されない。また，Fig 6 (b) に示したように, 電解研磨により表面の幾何学的形 状は平均化される。これは疲労強度を低下させる傷のば

Table III. Relation between the Vickers hardness and number of cycles to failure for EP-3.

\begin{tabular}{|l|r|l|l|}
\hline$\sigma_{\mathrm{a}} \mathrm{MPa}$ & $\mathrm{N}_{\mathrm{f}}$ cycles & Type $^{1}$ & $\mathrm{Hv}^{2}$ \\
\hline \multirow{2}{*}{1100} & 82110 & $\mathrm{~L}$ & 862 \\
\cline { 2 - 4 } & 21019180 & $\mathrm{SH}$ & 910 \\
\hline \multirow{2}{*}{1200} & 47800 & $\mathrm{~L}$ & 867 \\
\cline { 2 - 4 } & 32177870 & $\mathrm{SH}^{*}$ & 944 \\
\hline \multirow{2}{*}{1250} & 1545200 & $*$ & 938 \\
\hline \multirow{2}{*}{1350} & 11690 & $\mathrm{~L}$ & 881 \\
\cline { 2 - 4 } & 831600 & $\mathrm{U}$ & 954 \\
\hline \multirow{2}{*}{1400} & 12980 & $\mathrm{~L}$ & 887 \\
\hline \multirow{2}{*}{1500} & 146330 & $\mathrm{U}$ & 941 \\
\hline 1600 & 6850 & $\mathrm{~L}$ & 873 \\
\hline
\end{tabular}

1 Type in S-N plots (L: Lower limit, U: Upper limit,

SH: Super high-cycle fatigue, *: Fish-eye failure)

${ }^{2}$ Average of 6 to 10 points, Load $=2.94 \mathrm{~N}$

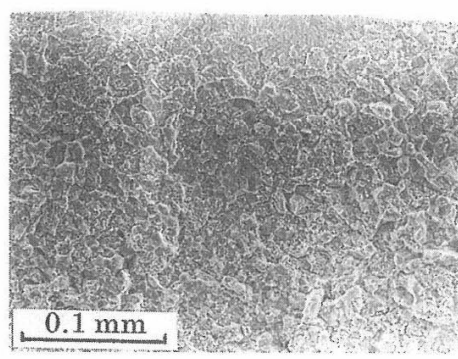

(b) EP-3

$\sigma_{2}=1500 \mathrm{MPa}, N_{f}=8.55 \times 10^{3}$

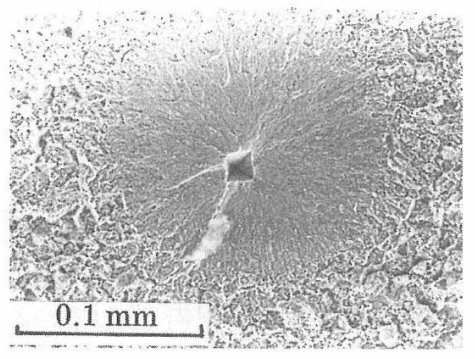

(c) EP-3

$\sigma_{a}=1300 \mathrm{MPa}, N_{f}=6.744 \times 10^{5}$
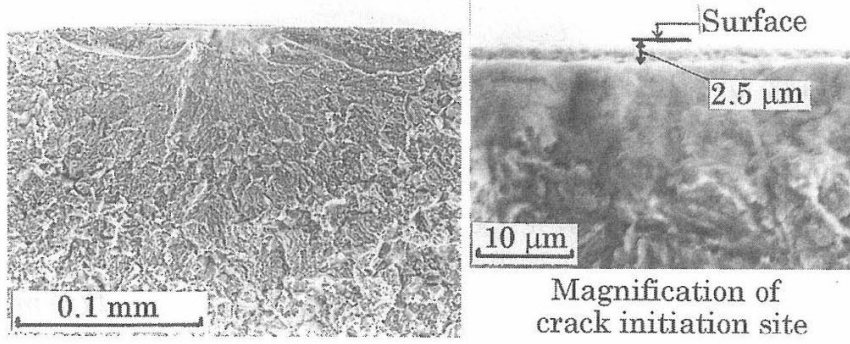

(d) EP-3

$\sigma_{a}=1100 \mathrm{MPa}, N_{f}=2.102 \times 10^{7}$

Fig. 9. SEM observations of the fracture surface of the electropolished specimens ;

(a) EP-15 specimen, and (b-d) EP-3 specimen. 
らつきが減少することを意味し，結果として疲労寿命の ばらつきは小さくなる。一方，EP-3 材と EP-0 材の平均 的寿命に大きな違いは認められない（ばらつきの幅は異 なるが，ほほ同じ位置に分布している)。これは，表面層 除去が, 表面強度（硬さ，残留応力）の低下をもたらす, 反面傷による切欠き効果の減少による疲労強度上昇とい う相反する作用を生じるためである。なお, 表面の除去 量を $3 \mu \mathrm{m}$ から増やしていけば，ばらつきの幅は狭くなり かつ平均寿命は EP-15 材の S-N 曲線に漸近していくこと になる。除去量が $15 \mu \mathrm{m}$ を越えれば，表面硬さの減少に より EP-15 材より疲労寿命・疲労限度とも多少低下する が，除去量が $25 \mu \mathrm{m}$ を十分越えれば除去量に依存しなく なるはずである。

\section{$3 \cdot 3$ 研削材の $\mathbf{S}-\mathbf{N}$ 特性と表面硬化層の関係}

RGSAMSの結果 (Fig. 4) に認妨えるように, 研削 材では $N=10^{7}$ 回付近から疲労強度が再低下寸るので全 体を従来型の S-N 曲線で表示するには無理がある。また， $10^{7}$ 回を基準とした疲労限度付近では短寿命側（表面起 点形）と長寿命側（内部起点形）のデータが混在する. 従って，これを単なるばらつきでなく，破榬起点の異な る S-N 曲線が異なる場所にずれて 2 重に現れたと考える 方が白然, すなおち「2 重 S-N 特性」と呼ぶべきとの指 摘 $^{9)}$ もある。このように $10^{7}$ 回瘦労限度付近から痩労強 度が再び低下したのは, 研削仕上げによる表面硬化層と

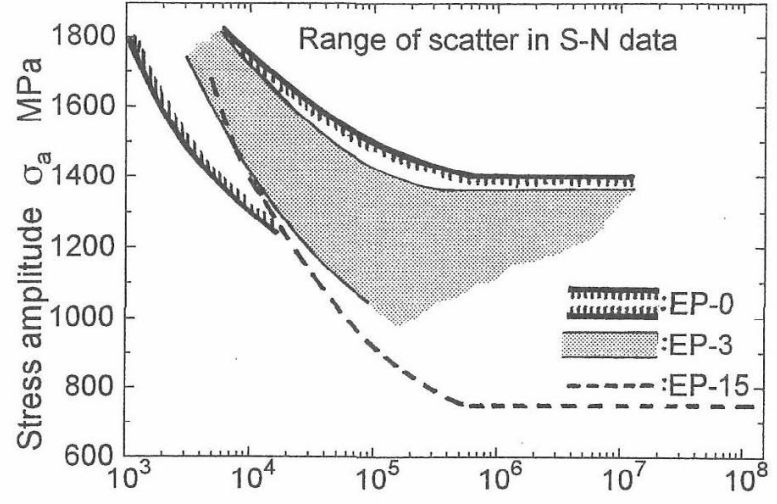

Number of cycles to failure $N_{f}$ cycles

Fig. 10. Comparison of scatter band of S-N data between the electropolished and ground specimens.
密接に関係する。すなわち, 研削後の表面は塑性変形を 受け加工硬化し, さらに压縮の残留応力が存在する。こ の部分に応力が繰返される場合, 微視的には予ひずみ材 に平均応力を与えさらに繰返し応力を加えている状態に 相当する。予ひずみ材の疲労被害および平均応力に関す

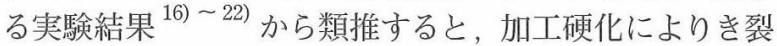
発生抵抗㧍よび初期き裂伝ぱ抵抗は増加すると考えられ る。一方, 圧縮の残留応力はき裂発生にはあまり寄与し ないと思われるが (平均応力はき裂発生にほとんど影響 しないことが報告 ${ }^{18), 19)}$ されている)，発生直後のき裂伝 ぱ速度を低下させる。結局，このような表面硬化層の存 在により，母材に比心゙疲学強度は大きく上昇する。しか しながら, 試験片内部の硬さは表面に比べ小さいため, 表面硬化層の痩労限度以下の応力下でも条件が揃えば内 部欠陥を起点としてき裂が発生する。内部起点形の破壊 には多くの繰返しを要するため長寿命側で痩労強度が低 下することになる。表面硬化層の影響をほとんど無視で きる EP-15 材の痩労強度が EP-0 材に比べ著しく低下し, かつ長寿命域での疲労強度の再低下（内部起点形破壊） が全く認められなかったことはこれを裏付けてる。

また，破壊起点が表面にある場合でも研削材の疲労強 度のばらつきは著しく大きい。電解研磨材の S-N 特性と の比較から, 疲労強度のばらつきは表面除去量の增加と 共に減少する。表面除去量の増加は表面の幾何学的形状 を平均化する方向に作用する。従って, 研削材の疲労強 度のばらつきは主として表面の研削傷のばらつきに起因 したものと思われる。

さらに，研削材の S-N 曲線 (Fig. 4) を見れば, $10^{7}$ 回 疲労限度付近では異なる破壊形態が混在し, 応力が大き くなれば表面破壤形が，小さくなれば内部破壞形が支配 的になっている。電解研磨材の結果を考慮すれば, 表面 起点形打よび内部起点形の異なる破猿形態が混在するの は, 主として研削による表面の幾何学的形状が試験片ご とに異なるためと考学られる。すなわち，試験片ごとに 表面形破壞の疲労限度を決定する傷の形状・寸法などが 異なるため, 同一応力を繰返しても破断する試験片と破 断しない試験片が存在する。表面から破断しなかった試 験片はその後の繰返しにより内部欠陥を起点として長寿 命域で破断することになる。このことは，表面状態が同 じ試験片だけを用いて実験を行えば，研削仕上げ材でも

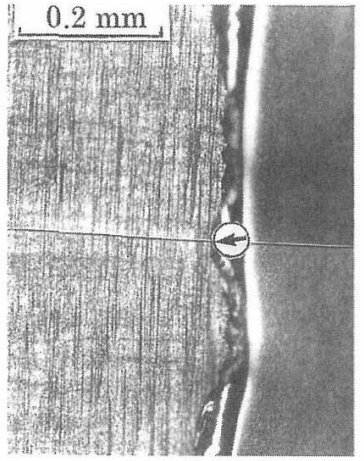

After fracture

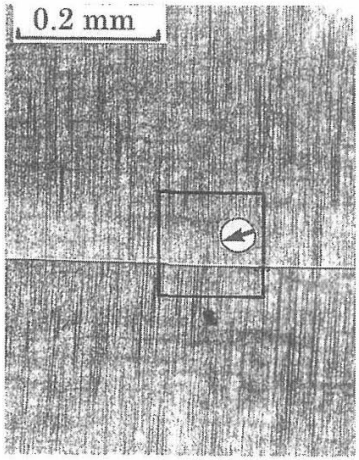

Before fracture

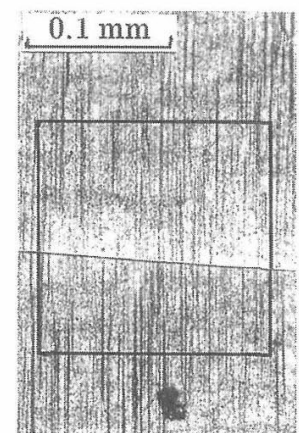

Magnification of crack initiation site

$\sigma_{a}=1350 \mathrm{MPa}, \mathrm{N}_{f}=16590$, Starting point of fracture

Fig. 11. Crack initiation site of EP-3 specimen whose fatigue life is plotted at the lower limit in the S-N band. 
S-N 曲線水平部以上の応力下では内部破壊形が現れない ことを意味する。しかしながら，実際の研削材において 試験片ごとに表面状態を揃えることは困難であり，同一 試験機にて実験条件を同じにしても Fig. 4 に示した S-N 特性が得られる。従って, 実用上は表面および内部からの 破壊の生起確率が応力により増減するとの解釈により疲 労寿命分布特性を調べ, 余寿命を評価するなどの試み ${ }^{23)}$ も必要である.

\section{4 結 論}

高炭素クロム軸受鋼 SUJ2 を用いて，研削仕上げした 試験片 (EP-0 材), 電解研磨にて表面硬化層の大部分を 除去（15 $\mu \mathrm{m}$ 除去）した試験片（EP-15 材），および表面 硬化層は有するが表面粗さを少なくした（3 $\mu \mathrm{m}$ 除去）試 験片（EP-3 材）の回転曲げ疲労試験を行い, 以下の結論 を得た。

(1) EP-0 材の S-N 曲線は，10 回付近から疲労強度が 再低下するいわゆる2段折れ曲がり現象を呈した。試験 片 10 本を用いて $10^{7}$ 回を打ち切り繰返し数としステアケ 一ス法により求めた疲労限度は $\sigma_{w 0}=1200 \mathrm{MPa}$ であり, これより応力が大きければ破壊の起点は表面に, 低けれ ば内部に存在する傾向にある。また, $\sigma_{w 0}$ 付近では両破 壊形態が混在する。なお, 疲労寿命のばらつきはいずれ の破壊起点の場合もかなり大きい.

(2) EP-0 材の表面には-500MPa を越える圧縮残留応 力が存在し，これは表面を $15 \mu \mathrm{m}$ 程度除去することによ りほぼ消滅した。また, 表面の Vickers 硬さは, EP-0, EP-3，EP-15 材についてそれぞれ $H_{v}=995 ， 910 ， 821$ 程 度である（素材の硬さ $H_{v}=777 ）$.

(3) EP-15 材の疲労強度は研削材より小さく, S-N 曲 線に明確な疲労限度 $\left(\sigma_{w 15}=750 \mathrm{MPa}=0.625 \sigma_{w 0}\right)$ が存在 する. S-N 曲線のばらつきは， EP-0 材に比べて著しく小 さい，また，破壊起点はいずれも表面であり，内部起点 形の破壊は認められない.すなわち, 本材料における(1) の EP-0 材の S-N 曲線に見られる 2 段折曲がり現象は， 研削仕上げに伴う表面強化層（加工硬化および圧縮残留 応力）に起因して起こる，以上の事実は，高強度材料に 見られる S-N 曲線の 2 段折曲がり現象が，必ずしも材料 に固有の現象ではないことを意味している.

(4) EP-3 材の S-N 曲線はばらつくが，ばらつきの幅 は EP-0 材に比べて小さい.ばらつきの幅が電解研磨に より小さくなるのは, 主として表面の幾何学的形状寸法 のばらつきが小さくなるためと思われる，一方， EP-0 材 と EP-3 材の S-N 曲線の平均值は大きく違わない.これ は, 表面強化層除去による疲労強度低下と, 表面粗さの 減少による疲労強度上昇の結果である.

(5) 研削材の S-N 曲線に見られる, 同一応力下で異 なる破壊形態が混在するのは，研削仕上げによる表面 状態のばらつきと内部起点のばらつきが関係すると思わ れる。

最後に, 本研究の一部は材料強度確率モデル研究会の 共同研究「高強度鋼の超長寿命確率疲労特性」の一環と して行ったものである. 試験片の製作および S-N データ などに関してご便宜いただいた同研究会の関係諸氏に深
く感謝する.また, 本研究は大分大学工学部生産システ 厶工学科学生（佐藤 誠, 山田真之介君（現大分大学大 学院学生)）の卒業研究として行われたものであり，実 験・データ整理等に関して両君の熱心な協力を得た。な お, 破面の SEM 観察は, 大分大学地域研究共同センタ 一の器材を使用した．記して謝意を表す。

\section{参 考 文 献}

1) T, Naito, H. Ueda and M. Kikuchi, Metal Trans., 15A, 1431 (1984).

2 ) 増田千利, 西島 敏, 田中義久, 日本機械学会論文集, A52, 847 (1986).

3) 江村秀樹, 浅見克敏，日本機械学会論文集，A-55，45 (1989).

4) 黒島義人, 清水真佐雄, 川寄一博, 日本機械学会論文集, A-59, 1820 (1993).

5）浅見克敏，弘永昌幸，材料， 43，12（1994）。

6）阿部孝行, 金澤健二, 材料, 45, 9（1996）.

7) C. Bathias and J. Bonis, Fracture From Defects, 1, 32 (1998).

8) 中村 孝, 金子真, 野口 徹, 神保勝久, 日本機械学 会論文集，A-64，1820（1998）.

9 ) T. Sakai, M. Takeda, K. Shiozawa, Y. Ochi, M. Nakajima, T. Nakamura and N. Oguma, Fatigue '99, 1, 573 (1999).

10）日本機械学会編，金属材料疲れ強さの設計資料（II），4 (1973).

11）渡辺正気，古市 博，日本機械学会論文集，C-56，2252 (1990).

12）渡辺正気，古市 博，日本機械学会論文集，C-57，1002 (1991).

13) M. Goto, T. Yamamoto, M. Sato, S. Yamada, N. Kawagoishi, T. Sakai and H. Nisitani, Proc. 2nd Inter. Conf. AMDP, I, 89 (1999).

14）村上敬宜, 野本哲志, 植田 徹, 村上保夫, 大堀 学, 日本材料学会第 24 回疲労シンポジウム講演論文集, p.111 (1998).

15）西谷弘信，今井良一，日本機械学会論文集，A-51，766 (1985)

16) N. E. Frost, Metallurgia, 57, 279 (1958).

17) S. J. Maddox, Int. J. Fract., 11, 389 (1975).

18）西谷弘信, 蓮尾康博, 日本機械学会論文集, 44,1 (1978).

19) 西谷弘信, 後藤真宏, 日本機械学会論文集, A-50, 1926 (1984).

20) 西谷弘信, 後藤真宏，日本機械学会論文集，A-51，440 (1985).

21）西谷弘信, 後藤真宏, 宮川浩臣, 日本機械学会論文集, A53, 378 (1987).

22）後藤真宏, 西谷弘信, 宮川浩臣, 三浦篤義, 日本機械学 会論文集, A-57, 1475 (1991).

23）材料強度確率モデル研究会, 日本材料学会第 48 期学術講 演会講演論文集, p.26 (1999). 